IRA-International Journal of Education \&

Multidisciplinary Studies

ISSN 2455-2526; Vol.17, Issue o3 (Q3, 2021)

Pg. no. 186-196.

IRA Academico Research

\title{
A Review of Studies on the Washback Effect of National Matriculation English Test (NMET) in China (2011-2020)
}

\author{
Li Rong ${ }^{1 \# ~(i) ~ \& ~ P e n g ~ Y i ~}$ \\ \# corresponding author \\ Type of Work: Peer Reviewed. \\ DOI: 10.21013/jems.v17.n3.p10 \\ DOI URL: https://dx.doi.org/10.21013/jems.v17.n3.p10
}

${ }^{1,2}$ School of Foreign Studies, Yangtze University. Hubei, 434023 P.R. China.

\section{How to cite this paper:}

Rong, L., Yi, P. (2021). A Review of Studies on the Washback Effect of National Matriculation English Test (NMET) in China (2011-2020). IRA-International Journal of Education \& Multidisciplinary Studies (ISSN 2455-2526), 17(3), 186-196.

DOI: https://dx.doi.org/10.21013/jems.v17.n3.p10

(C) IRA Academico Research.

(c) EY-No This work is licensed under a Creative Commons Attribution-NonCommercial 4.0 International License subject to a proper citation to the publication source of the work.

Disclaimer: The scholarly papers as reviewed and published by IRA Academico Research are the views and opinions of their respective authors and are not the views or opinions of IRA Academico Research. IRA Academico Research disclaims any harm or loss caused due to the published content to any party.

IRA Academico Research is an institutional publisher member of Publishers International Linking Association Inc. (PILA-CrossRef), USA. IRA Academico Research is an institutional signatory to the Budapest Open Access Initiative. Hungary advocating the open access of scientific and scholarly knowledge. IRA Academico Research is a registered content provider under Open Access Initiative Protocol for Metadata Harvesting (OAl-PMH).

The journal is indexed \& included in WorldCat Discovery Service (USA), CrossRef Metadata Search (USA), WorldCat (USA), OCLC (USA), Open J-Gate (India), EZB (Germany) Scilit (Switzerland), Airiti (China), Bielefeld Academic Search Engine (BASE) of Bielefeld University, Germany, PKP Index of Simon Fraser University, Canada.

\footnotetext{
Li Rong (10)/0000-0002-9130-9286

Peng Yi (i) /0000-0002-5846-5375
} 


\begin{abstract}
This paper reviews the washback studies in National Matriculation English Test (NMET) in the past decade (2011-2020). There are 36 Chinese works of literature collected from CNKI (China National Knowledge Infrastructure), all of which are searched by keywords "National Matriculation English Test "(NMET) and "washback effect". And This literature is divided into two levels: micro level and macro level. The micro-level includes 5 categories, and the macro-level includes 3 categories. After analyzing and discussing, the researcher finds that: (1) The research has increased sharply before 2018 and is greatly influenced by policies; (2) The proportion of empirical research is equal to that of non-material research, which is dominated by empirical research at present; (3) The research mainly involves the washback effect of NMET, its reform and test typesetting at the macro level; Micro-level listening, speaking, reading, writing, grammar filling washback. Through the analysis, it is found that the main problems of the research on the washback effect of NMET include lack of innovation, neglect of listening and speaking skills, lack of depth of research, little attention to students -the subject of the test, and neglect of the long-term effect of the washback. Finally, some suggestions are put forward based on the above problems.
\end{abstract}

Keywords: College Entrance Examination English; Washback Effect; NMET

\title{
1. Introduction
}

The washback effect, a research field in applied linguistics, refers to the impact of language testing on teaching and learning, as well as the positive or negative impact of language testing on curriculum setting, educators and talent cultivation (Hughes, 1989; Bachman \& Palmer, 1996). Heaton (2000) points out that the nature of test washback is mainly determined by the quality of the test. High-quality tests have a positive impact on teaching and learning, and vice versa. NMET in China is a large-scale, standardized test, is also the "baton" of high school English teaching, its reflected high quality is beyond doubt (Popham, 1987). In addition, examinations can play a direct decisive role in teaching. "How examinations are conducted, how teachers will teach" (Popham, 1987). Obviously, the washback effect of studying NMET cannot be ignored. At present, the steady progress of the new College Entrance Examination makes the education circle in China pay more and more attention to the influence of NMET on education, and the washback effect has become one of the hot spots of language test research. The purpose of this study is to make researchers understand the current situation of the research on the washback effect of NMET in recent ten years in China, the reflection and the further suggestion of it, so as to promote further research on the washback effect of NMET, and provide some reference for the future related research. This paper attempts to search and analyze the domestic literature on the washback effect of NMET in the recent ten years.

\section{Literature Search Scope}

Based on the keywords "National Matriculation English Test "(NMET) and "washback effect", the author selected 36 pieces of Chinese literature from 2011 to 2020 from CNKI, with the minimum cited number of literature being 1 or the minimum downloaded number of literature being 300 as the first criterion and publications related to education teaching or English teaching as the second criterion.

\section{The Research Status of Washback Effect of NMET}

\subsection{Basic research trends}


According to the statistics and analysis of 36 pieces of literature (see Figure 1), the research on the washback effect of NMET in the past decade showed a slow upward trend from 2011 to 2017 but showed explosive growth in 2018 and a downward trend from 2019 to 2020. For the surge in the number of 2018, mainly because in October 2017, the Ministry of Education puts forward China will set up a new college entrance examination system in an all-round way, which plays a big role in promoting NMET washback research. Scholars have closely followed the education policy, and actively studied and discussed the reform of the college entrance examination system and the washback effect it will bring to teaching.

Figure 1 Research development trend of NMET washback effect from 2011 to 2020

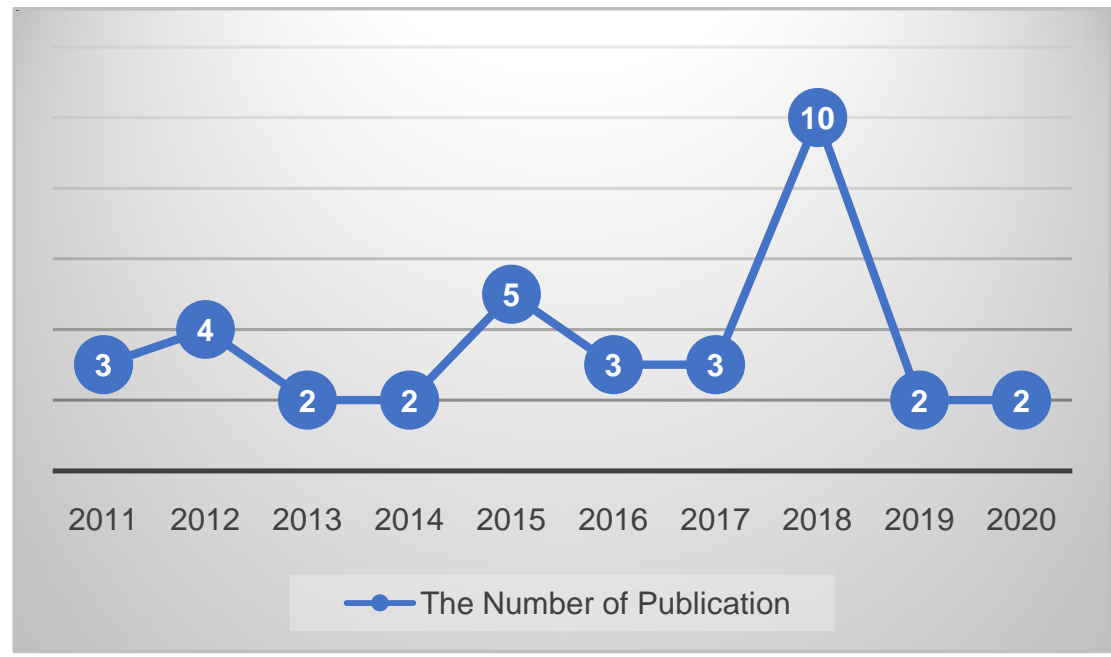

\subsection{The Research Methods}

According to Gao Yihong et al. (1999), research can be divided into empirical research and non-material research (non-empirical research). Empirical research refers to a research paradigm that solves research problems, verifies research hypotheses or constructs theoretical frameworks through the data and materials collected by researchers themselves. The data collected mainly includes qualitative and quantitative forms or mixed forms. Non-empirical research refers to the research that is not based on systematically collected materials, mostly personal views, opinions and summaries, speculative discussions on theories or existing studies, and specific operational descriptions and evaluations. Based on these two categories, this paper classifies 36 pieces of literature on the washback effect of NMET, as shown in Table 2:

Table 2 The use of methods in the study on the washback effect of NMET from 2011 to 2020

\begin{tabular}{|l|r|r|r|r|r|r|r|r|r|r|r|}
\hline Mehtod & & 2011 & 2012 & 2013 & 2014 & 2015 & 2016 & 2017 & 2018 & 2019 & 2020 In Total \\
\hline Empirical Research & Number & 2 & 3 & & 2 & 2 & 2 & 1 & 5 & & 1 \\
\hline Non-material Research & Nmuber & 1 & 1 & 2 & & 3 & 1 & 2 & 5 & 2 & 1 \\
\hline
\end{tabular}

Table 2 shows that in recent 10 years, the number of studies using empirical methods and non-material methods was 18 respectively, which was relatively consistent with the conclusion drawn by Zhang Jianzhen (2012) on the selection of research methods in the washback effect of foreign language testing from 2001 to 2010. In empirical research, questionnaires, interviews, classroom journals and classroom observations are mostly used as the main forms of research. In order to ensure the validity and credibility of research results, researchers usually combine two or more research forms to analyze research problems from a more comprehensive perspective. Due to the small number of literature selected, and the number of some years is 0 , it is difficult to give an accurate explanation of the research trend. 


\subsection{The research content}

Li Xiaoju et al. (1990) found that NMET promotes the reform of middle schools, and English courses increase the training of listening, speaking, reading and writing skills, which changes the situation that originally only focused on knowledge teaching. In recent years, most experts and scholars have not only studied and discussed the washback effect of NMET on teaching from the micro-level of different test types such as listening, speaking, reading, writing and grammar filling, but also from the macro perspective of the whole test type design, NMET as a whole and its reform. Therefore, according to the research content of the washback effect of NMET, this paper divides 36 pieces of literature into two levels: micro level and macro level. The micro-level includes 5 categories, and the macro-level includes 3 categories.

Table 3 The content classification of the research on the washback effect of NMET

\begin{tabular}{|c|c|c|c|}
\hline \multirow{4}{*}{$\begin{array}{c}\text { Micro } \\
\text { Level }\end{array}$} & Category & Research Content & Number \\
\cline { 2 - 4 } & 1 & The effect of Reading Comprehension on teaching & 5 \\
\cline { 2 - 4 } & 2 & The effect of Writing (Continuation Task, marking criterion) on & 7 \\
\cline { 2 - 4 } & 3 & teaching & 4 \\
\cline { 2 - 4 } & 4 & The effect of Speaking on teaching & 4 \\
\hline
\end{tabular}

\begin{tabular}{|c|c|c|c|}
\hline \multirow{4}{*}{$\begin{array}{c}* \\
\text { Macro }\end{array}$} & Category & Research Content & Number \\
\cline { 2 - 4 } & 1 & The effect of test type design on teaching & 1 \\
\cline { 2 - 4 } & 2 & The effect of NMET on teaching & 9 \\
\cline { 2 - 4 } & 3 & The effect of NMET Reform on teaching & 4 \\
\hline
\end{tabular}

According to the two levels in Table 3, it can be seen that at the micro-level, researchers pay more attention to the washback effect of writing and reading, followed by listening and speaking and grammatical filling. The least attention is paid to the washback effect of listening because teachers have designed the listening training when training students to listen and speaking, which is more efficient and can better reflect the integrity of listening and speaking. At the macro level, researchers prefer to grasp the washback effect of NMET on teaching as a whole to achieve the effect of "the whole is greater than the sum of the parts", which accounts for the highest proportion. Next comes the attention to the reform of NMET, while the design of test types is almost ignored, which may be related to the actual teaching concerns. The key and difficult points of teachers' teaching are little affected by test types but are almost closely related to the Test Syllabus.

\subsubsection{The effect of Reading Comprehension on teaching}

The NMET Syllabus points out that students' independent reading ability should be cultivated, and reading comprehension, as the largest part of the college entrance examination paper, plays an important role in teaching and learning. However, the current reading teaching attaches too much importance to the teaching of language knowledge but ignores the cultivation of students' reading ability advocated by the Syllabus. Yang Min (2015) believes that teachers should focus on reading materials in textbooks, train reading skills, and practice the combination of reading and writing. Tang Yu (2018), Liu Lianghua (2018) and Wu Yushui (2020) believe that extensive extracurricular reading on this basis is also necessary, and teachers' roles should be adjusted accordingly. Yang Min (2015) and 
Tang Yu (2018) emphasized that test organizers need to provide teachers with relevant testing knowledge to help them analyze and evaluate test results and play a positive washback role of NMET. Different from the former, Sun Wenna (2015) pointed out that the status of NMET should be weakened, the unpredictability of questions should be increased, and the structure of examination questions should be reformed. To some extent, this is unrealistic and irrational, which will indirectly increase the burden on students and teachers.

\subsubsection{The effect of Writing on teaching}

NMET writing is best for testing students' comprehensive language application ability. It not only requires students to master basic language knowledge such as words, grammar and syntax but also has certain requirements on writing logic, text structure, topic determination and logical thinking ability. This has a certain washback effect on teachers' teaching. Zeng Yan (2012) found that after the new curriculum reform, writing teaching activities became more diversified, materials were closer to students' real life, and propositions were more open. Moreover, together with Hu Siqing (2016), Zhou Xueyi (2017) and Xia Rui (2018), she put forward five blowback effects that NMET writing brings to teaching, namely, from knowledge-based teaching to skill-based teaching in terms of teaching philosophy; In terms of teaching methods, the emphasis has shifted from the result of writing to the process of writing; The role of teachers and students has changed from teacher-led to student-led; In teaching means, making full use of modern technology; In teaching evaluation, paying attention to the diversity of evaluation subjects and the "significance" of evaluation. However, due to the time schedule of writing, teachers' understanding of the test, school evaluation system and social pressure, NMET has brought some negative washback effects on writing teaching. Wang Zhen (2011) sorted out and analyzed common writing problems in the process of marking NMET papers, and then discussed their washback effect. He proposed to cultivate students' writing sense from a multi-dimensional perspective, inspire students' thinking through process writing, and advocate a multi-subject writing evaluation system. Xiong Yanyan (2016) looked at the washback effect of NMET from the perspective of writing evaluation standards. She believes that it is more objective and fair to guide students' writing according to evaluation standards and test syllabus and help students to clearly position themselves and solve their own problems. Yang E (2018) analyzed the washback effect of NMET from the perspective of writing test analysis. She found that the writing of NMET is mainly practical, with richer themes and higher openness, which is closer to students' life. In teaching, materials around students should be explored, students' open thinking should be encouraged, and students' habits of making outline drafts should be cultivated to improve their writing ability.

\subsubsection{The effect of Speaking on teaching}

Based on the new curriculum standards, Shanghai and Guangdong have included speaking tests in NMET. The addition of the speaking test has achieved a real comprehensive language ability training, in line with English Key Competencies. For the washback effect brought by it, scholars through empirical research, Wu Pingping (2011) found that teachers have infiltrated the teaching of speaking in both teaching content and teaching activities, which also affects students' learning concept, behaviour and motivation. Zhang Fang (2014) found through the BAK theory model that teachers deviated from the original intention of the test designer in the teaching process, and the reform goal of the test could not be fully implemented. Hou Yanping (2018) further pointed out that teachers attach more importance to the teaching of listening and speaking strategies and the development of listening and speaking 
research. Zhang Rong (2019) found that the school has increased many hardware and software facilities so that students are more consciously and conscientiously completing listening and speaking homework, and their participation in class has also been greatly improved. In terms of negative washback, the teaching method is still exam-oriented, and the proportion of listening and speaking practice is not balanced.

\subsubsection{The effect of Grammatical Filling on teaching}

The grammatical filling test focuses on students' pragmatic competence and examines students' comprehensive language useability from the perspective of discourse, which has got rid of the boring and monotonous grammatical focus test in the past and is bound to play a certain washback effect on teaching. Zhang Fan (2015) and Lian Shihua (2017) believe that grammar fillings promote the integration of context in grammar classes, help master basic grammar knowledge more comprehensively, strengthen students' grasp of word spelling and form, and encourage teachers to integrate grammar knowledge into reading teaching. An Yan (2018) further emphasized that teachers should emphasize the skills of grammatical filling and guide students to carry out the adequate practice. Zhou Shuang (2018) believes that grammar filling requires teachers to classify and strengthen grammar according to primary and secondary grammar. In the form of the flipped classroom, student-centred grammar teaching can cultivate students' abilities of independent inquiry and learning, increase the input of life discourse, and carry out corresponding grammatical adaptation and practice.

\subsubsection{The effect of Listening on teaching}

Listening is not only an important skill in foreign language teaching but also an important part of comprehensive language competence. A few years ago, there was no unified requirement for the listening test in NMET, which resulted in the inability to improve students' listening levels. In view of the phenomenon at that time, scholars have found some way out for a positive washback effect in NMET listening. Wu Huidi (2012) argue that the NMET listening test improves the teachers' degree of attention to it, such as increase the number of listening classes, supplement listening material, impart corresponding skills, but there are traces of "excessive assignments tactic", the teaching method is unitary, it failed to boost the enthusiasm of the students' initiative in listening. The research results of Dong Lianzhong (2017) also found these phenomena and proposed to reduce the proportion of objective English questions and increase extracurricular listening input, so as to promote the positive washback effect of NMET on listening teaching.

\subsubsection{The effect of test type design on teaching}

The test design of NMET aims to examine students' ability to analyze and solve problems, to use language flexibly based on their basic knowledge and skills. Based on the syllabus of NMET, Zhao Huifeng (2018) studied the washback effect of the setting of test questions on teaching and learning. He holds that the setting of test questions plays a positive washback on teachers' teaching organization, the emphasis and difficulty of learning, the cultivation of students' thinking ability, the use of teaching methods, teachers' teaching reflection, the grasp of proposition characteristics, and the improvement of students' consciousness of examination norms. The negative washback effect is mainly reflected in the incomplete students' evaluation system, taking examination results as the only evaluation standard, and the lack of emphasis on English speaking and listening. 


\subsubsection{The effect of NMET on teaching}

With the advancement of the new curriculum standard, in-depth analysis of the washback effect of NMET on teaching plays a pivotal role in providing direction for teachers' English teaching activities and improving teaching quality. Many researchers analyze the washback effect of NMET from a macroscopic perspective. Xia Lili (2012) and Tan Xiaoping (2011) focused on the negative washback effect of NMET and found that exam-oriented education was the prevailing trend, bringing spiritual and psychological pressure to teachers and students. Everything was subject to NMET, teaching for the examination and learning for the examination. Song Guannan (2013) found that the materials used by students were closer to real-life according to NMET, but the training of listening and speaking skills was neglected, knowledge irrelevant to NMET was not taught at all, and teachers' teaching evaluation was based on students' NMET scores. Dong Lianzhong (2014) further found that the prevalent communicative approach in recent years caused students to neglect the learning of basic grammar knowledge and students' grammar thus was weak. Facing the phenomenon of examination restricting education at present, this Education Ministry puts forward the tentative idea of exploring the development mode of diversified talents. After the new curriculum standard came out, some changes took place in the research conclusions. Wu Zongyou (2015) emphasized the test outline shows that teaching is more focused on language skills training, more to promote the implementation of the teaching outline. Also, Ma Yuxin (2015) found that teachers prepare a lesson more seriously, but they both agree teaching is under the influence of NMET and ignore the use of language, the classroom is still a teacher-led classroom, students still are passive recipients. Dong Manxia (2018) found that NMET has a significant washback effect on the types of classroom teaching activities, materials used, teaching content and assignment through the study of class journals. This is roughly the same as the research result of You Hongjing (2019) and suggests that teachers should carefully study the new curriculum standard, improve their professional quality, reasonably arrange teaching activities and set up diversified homework. Zhang hao (2020) breaks through the previous limitations like the small sample size and narrow sample range, the lack of delving into research, and conducted a national survey about the washback effect, found that NMET stimulates students learning motivation and enhance interest in learning English, improve the students' overall English level plays a positive washback effect. The most novel finding is that a teacher's seniority and the difficulty of admission to the school where he teaches, the city where he teaches and the highest degree of a teacher have a great influence on how teachers view the washback effect of NMET.

\subsubsection{The effect of NMET Reform on teaching}

This category is divided into two parts with the 2014 NMET reform as the dividing line. Before 2014, the NMET has a lot of negative washback on teaching, scholars urgently hope for a new round of NMET reform, Tan Xiaoping (2011), Wang Youping (2013) pointed out that the current English teaching has a certain gap with the ideas put forwards by the new curriculum reform, so NMET is badly in need of reform in keeping with the curriculum reform. In order to overcome the negative washback effects of exam-oriented education, it proposes clear teaching objectives and changes teaching concepts for the new round of NMET reform, updates teaching contents and changes teaching methods, constructs the multi-evaluation system and so on. After the NMET reform was implemented in 2014, scholars investigated the washback effect of the reform on teaching and learning. Wang Wenting (2016) found that the implementation of "two tests a year" helps English classroom teaching mode transfer to the quality education, set up the oral English course, increase students' interest in 
English, reduce the test pressure, give students more autonomy to choose learning content and learning style in order to cultivate students autonomous learning. But it is also found that teachers' class hours increased, virtually increased the teacher's psychological pressure. Through investigation, Chen Yanjun (2018) further found that the improvement of writing scores increased the training and emphasis on improving writing skills. However, "two tests a year" also shows that the focus on oral English is not enough, students invest more in English learning, learning burden is increased too, teachers in the test time setting also showed dissatisfaction and maladaptive.

\section{Reflections on the Washback Effect of NMET}

After sorting out and summarizing the literature on the washback effect of NMET in recent ten years, it is found that:

1. The proportion of empirical research is increasing year by year, and scholars pay more attention to verify their research content through data in order to be more accurate and convincing. Research methods usually include at least two or more, such as questionnaires, classroom observation, interviews, etc.

2. Compared with the past, scholars only focus on analyzing the washback effect of NMET from a macro perspective, now scholars analyze and discuss the washback effect from a more comprehensive and complete perspective in the micro and macro levels.

But there are some problems:

i. The number of studies published in major domestic journals in recent years is insufficient, and there are a large number of journals with great similarity in content, structure and conclusion, and lack of innovation;

ii. Although a lot of literature studies listening, speaking, reading and writing, they mainly focus on reading and writing, and pay little attention to speaking and listening, because the score of the test is very low or not included in the total score.

iii. Most of the studies are from the perspective of teachers, but there are only a few studies on the washback effect of NMET from the perspective of students. Moreover, there are no studies on the washback effect of NMET related personnel on teachings, such as test designers and textbook developers.

iv. The quantitative research is not accurate in the control and operation of variables, and there are few planned data analyses and organized empirical research. The number of samples selected is insufficient, the representativeness is not high, or the investigation is only carried out for a certain grade, but lacks comparative research for each grade;

v. In the studies on the washback effect of NMET, scholars almost only focus on the washback effect generated during the preparation period for the examination, instead of exploring and analyzing the influence of NMET on students from a long-term perspective, such as what lasting influence NMET will have on students and teachers after the examination is over.

\section{Prospects for future research on the washback effect of NMET}

In view of the shortcomings of the above-mentioned research on the NMET washback effect, the researcher puts forward the following prospects for these problems:

(1) Researchers should jump out of the frame of thinking and try to find different washback effects from the perspective of NMET in a new way and dimension. For example, Zhang Hao (2020) found that there was a relationship between the washback effect of NMET and 
teachers' teaching age, highest educational background, city of employment, etc. Different from previous research conclusions, he jumped out of the paradigm of previous research and found new aspects. Therefore, researchers should try to explore the perspective that has not been involved before or carry out deeper and more detailed research on the previous findings, and strive for innovation and development, rather than repeating and mechanically summarizing the existing literature.

(2) Attention should be paid to the research on the washback effect of listening and speaking. The New Curriculum Standard for Senior High Schools (2017) emphasizes the cultivation of students' language competence to understand and express meaning by listening, speaking, reading, viewing and writing in a social context, and some provinces and cities have included listening and speaking test in the total score of NMET. Researchers should keep up with this trend, pay attention to the washback effect of listening and speaking tests on teaching, test the compatibility between teaching and the requirements of the new curriculum standard, and provide operational suggestions for middle school teachers to improve the quality of teaching.

(3) While paying attention to teaching, we need to pay more attention to the subject of examination -- students. Some scholars, including Wang Wenting (2016), have found that NMET will affect students' learning contents, learning methods and learning attitudes. Students are the direct participants of the examination, so the washback effect of examination on students cannot be ignored inevitably. Researchers should pay more attention to the washback effect from the perspective of students.

(4) For the study of the washback effect of NMET, researchers should carry out a more in-depth and detailed research and try to detect the difference of washback effect in different environments, like in schools or educational institutions. We can also try to discuss the washback effect of testing personnel, and try to understand the washback effect from a more comprehensive perspective, so as to provide help for the improvement of teaching quality.

As the riskiest examination in China, the college entrance examination's washback effect cannot be ignored. The research of the washback effect plays an important role in helping teachers discover the influence of college entrance examination on teaching and provides some reference for future English reform. Through sorting out and analyzing the research on the washback effect of NMET in the recent ten years in China, the researcher hopes to provide some help to the scholars who intend to explore this area.

\section{References}

[1]. Bachman, L. F., \& Palmer, A. S.(1996). Language Testing in Practice [M].Oxford: Oxford University Press.

[2]. Hughes, A. (1989). Testing for Language Teachers [M].Cambridge: Cambridge University Press.

[3]. Heaton, J. B. (2000). Writing English Language Tests [M]. Beijing: Foreign Language Teaching and Research Press.

[4]. Popham, W. J. (1987). The merits of measurement-driven instruction. Phi Delta Kappan, 68(9), $679-682$.

[5]. An Yan. (2018). An analysis of the washback effect of grammar fill-in-the-blanks on English teaching in senior high schools. New Curriculum (09), 227.

[6]. Chen Yanjun \& Cai Jinting.(2018). Research on the Washback effect of the New Mode of National Matriculation English Test. Foreign Language Research (01), 79-85.

[7]. Dong Lianzhon. (2014).On the washback effect of National Matriculation English Test-- 
Based on a questionnaire survey of freshmen in a university. Foreign Language Testing and Teaching (02), 54-59, 64.

[8]. Dong Lianzhong. (2017).Research on the washback effect of National Matriculation English Listening Test. Foreign Language Testing and Teaching (01), 42-49.

[9]. Dong Manxia. (2018).A study on the washback effect of NMET on high school English classroom teaching. Basic Foreign Language Education, 20(02), 25-32, 107.

[10]. Gao Yihong. (1999).Trends of research methods in Applied linguistics in China and The West. Foreign Language Teaching and Research (2), 8-16.

[11]. Hou Yanping. (2018).Research on the washback effect of the Reform of Listening and Speaking Test in NMET. Technology Enhanced Foreign Language Education (05), 23-29.

[12]. Hu Siqing. (2016).The washback effect of National Matriculation English Writing Test on writing teaching in senior high school. Teaching \& Research in Writing (06), 114.

[13]. Li Xiaoju \& Gui Shichun.(1990). NMET Test Design and Middle School English Teaching. Foreign Language Teaching in Schools (01),23-29.

[14]. Lian Shihua. (2017).An analysis of the washback effect of grammar filling in NMET on English teaching. Educational Practice and Research (Z1), 113-114.

[15]. Liu Lianghua. (2018).The washback effect of National Matriculation English Reading Comprehension Test on High School English Teaching.Xue Yuan Education (14), 69, 71.

[16]. Ma Yuxin. (2015).Analysis of the washback effect of National Matriculation English Test on English teaching in senior high school [J].Yu Shu Wai Xuexi (12), 42-43.

[17]. Song Guannan. (2013).An analysis of the washback effect of National Matriculation English Test on English teaching in senior high schools. College Entrance Examination (07), 112.

[18]. Sun Wenna. (2015).A study on the washback effect of National Matriculation English Reading Comprehension Test on High School English Teaching. Science and Technology Innovation Herald, 12(23), 157-158.

[19]. Tan Xiaoping \& Dai Yongcai.(2011).A survey of the washback effect of NMET on English teaching in senior high schools. Success Magazine (14), 210-213.

[20]. Tan Xiaoping. (2012).On the reform of English teaching in senior high school from the washback effect of NMET. Time Education(15), 2-3.

[21]. Tang Yu. (2018).The washback effect of National Matriculation English Reading Comprehension Test on Teaching[J].New Education (11), 51-53.

[22]. Wang Wenting \& Ying Chunyan.(2016).Explore the washback effect of NMET reform on English exam-oriented education in Jiangsu Province. English on Campus (15), 126-127.

[23]. Wang Youping. (2013). Analyze the reform of High School English Teaching through the washback effect of NMET. College Entrance Examination (03), 14.

[24]. Wang Zhen. (2011). The washback effect of National Matriculation English Test on teaching -A Case study of Zhejiang's written expression paper in 2010 National Matriculation English Test. Teaching Monthly (Middle School Edition)(04), 59-61.

[25]. Wu Huidi. (2012). The washback effect of National Matriculation English Listening Test on English teaching in senior high school in Zhejiang Province. Educational Measurement and Evaluation (02), 54-58.

[26]. Wu Pingping. (2011).The washback effect of National Matriculation English Listening and Speaking Test on High School English Teaching. Basic Foreign Language Education,13(04), 12-19.

[27]. Wu Yushui. (2020).Discussion on the washback effect of National Matriculation English Test on English reading teaching in senior high school. Kaoshi Zhoukan (69), 93-94.

[28]. Wu Zongyou. (2015).An empirical study on the washback effect of National Matriculation English Test on high school English classroom teaching. Education and Examinations (01), 28-31. 
[29]. Xia Lili. (2012).Analysis of the washback effect of National Matriculation English Test on English teaching in senior high school. English Journal for Middle School Students (20), 33.

[30]. Xia Rui. (2018).Discussion on the washback effect of National Matriculation English Writing Test on English writing teaching in senior high school. Overseas English(20), 109-110.

[31]. Xiong Yanyan. (2016).Analysis of the effect of National Matriculation English Writing Score on English writing teaching. English Journal for Middle School Students (30), 73.

[32]. Yang E. (2018).Analysis of English Writing in National Matriculation English Test and its washback effect on English writing teaching in senior high school. Kaoshi Zhoukan (37), 115, 131

[33]. Yang Min. (2015). The washback effect of National Matriculation English Test on English reading teaching in senior high school. Journal of Hubei Open Vocational College, 28(03), 156-157.

[34]. You Hongjing. (2019).Discussion on the washback effect of National Matriculation English Test on High School English Teaching. Motherland (11), 273, 277.

[35]. Zeng Yan \& Liu Jinming. (2012).The washback effect of National Matriculation English writing Test on English writing teaching in senior high school. Theory and Practice of Contemporary Education,4(03), 11-14.

[36]. Zhang Fan \& Fu Fuying. (2015). The characteristics of "fill-in-the-blank" in National Matriculation English Test and its washback effect on grammar teaching. Crazy English(Pro)(01), 77-79.

[37]. Zhang Fang. (2014). A study on the washback effect of English Listening and Speaking in National Matriculation Test of Guangdong Province: BAK Consciousness System and Test Preparation Behavior of Teachers. Foreign Language Testing and Teaching (03), 44-49.

[38]. Zhang Hao \& Zhang Wenxia. (2020). The washback effect of National Matriculation English Test on high school English teaching from the perspective of high school English teachers: Based on a large-scale national survey. Foreign Language Learning Theory and Practice (03), 36-45.

[39]. Zhang Jianzhen. (2012).Review and Prospect of studies on the washback effect of English Language Testing in China -- a statistical analysis of nine major foreign language journals in China. Foreign Language Testing and Teaching, 000(003), 27-33.

[40]. Zhang Rong. (2019). The washback effect of Listening and Speaking Test of National Matriculation English Test in Shanghai under the background of NMET Reform -- Taking J school as an example. Foreign Language Testing and Teaching (04), 47-53.

[41]. Zhao Huifeng. (2018). The washback effect of the setting of English test types in National Matriculation English Test on foreign language teaching. College Entrance Examination (30), 207.

[42]. Zhou Shuang. (2018).Analysis of Grammar Fill-in questions in National Matriculation English Test from 2016 to 2018 and its washback effect on grammar teaching. English Teachers,18(17), 82-88.

[43]. Zhou Xueyi. (2017).The washback effect of National Matriculation English Writing Test on high school English writing teaching. English Journal for Middle School Students (42), 120. 